\title{
Survival and injuries of Deois flavopicta (Stal., 1854) in pastures under seed treatment with insecticides and dry mass yield
}

\section{Sobrevivência e injúrias ocasionadas por Deois flavopicta (Stal, 1854) em pastagens submetidas a tratamento de sementes com inseticidas e produtividade de massa seca}

\author{
Marcelo Francisco Arantes Pereira ${ }^{*}$, Alvaro de Favare Junior², Alexander Machado Auad ${ }^{3}$, \\ Marilia Gregolin Costa²
}

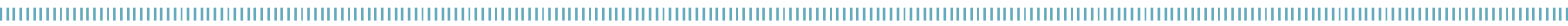

\begin{abstract}
The present study evaluated the survival and injuries of Deois flavopicta (Hemiptera: Cercopidae) in pastures of Urochloa (Syn. Brachiaria) decumbens and U. brizantha, submitted to seed treatment with fipronil $\left(\right.$ Amulet $\left.{ }^{\circledR}\right)$ and thiamethoxam (Cruiser $\left.350 \mathrm{FS}^{\circledR}\right)$, and dry mass yield. The experiment, carried out at the APTA Experimental Unity, São José do Rio Preto, SP, Brazil, was designed in randomly blocks, with six treatments (factorial $2 \times 3$ ) and four replications. Sowing was manual, with $12.0 \mathrm{~kg} \mathrm{ha}^{-1}$ seeds. Twenty adults were released on the plot, in a 40x40x70 cm cage, forty-nine days after sowing. The insects were sampled every two days during twelve days, without replacement of dead insects. Injuries caused by the spittlebug were evaluated by a rating scale and by productivity (dry mass yield). Data were analyzed by F-test and means compared by Tukey's test ( $\mathrm{p} \leq 0.05)$. The survival of adults was higher in the $U$. decumbens pasture than in the $U$. brizantha pasture. Results show that seed treatment with thiamethoxam reduced the survival of D. flavopicta in pasture formation, but did not influence the injuries caused by insect and the dry mass yield of forage species.
\end{abstract}

KEYWORDS: Spittlebug; Urochloa decumbens; Urochloa brizantha; integrated pest management.
RESUMO: Objetivou-se avaliar a sobrevivência e injúrias causadas por Deois flavopicta (Hemiptera: Cercopidae) em pastagens de Urochloa (Syn. Brachiaria) decumbens e U. brizantha, submetidas a tratamento de sementes com fipronil (Amulet ${ }^{\circledR}$ ) e tiametoxam (Cruiser $350 \mathrm{FS}^{\circledR}$ ), bem como à produtividade de massa seca. A pesquisa foi desenvolvida na Unidade de Pesquisa e Desenvolvimento de São José do Rio Preto/Agência Paulista de Tecnologia dos Agronegócios, sob o delineamento de blocos ao acaso, com seis tratamentos (fatorial $2 \times 3)$ e quatro repetiçôes. A semeadura foi realizada manualmente, distribuindo $12,0 \mathrm{~kg} \mathrm{ha}^{-1}$ de sementes. Para infestação, foram liberados 20 adultos, em gaiolas de 0,40x0,40x0,70 m, aos 49 dias após a semeadura, e a contagem dos insetos nas gaiolas foi conduzida a cada dois dias, por um período de 12 dias, sem a substituição dos insetos mortos. Em avaliação visual foram atribuídas notas de injúrias causadas pela cigarrinha-das-pastagens às gramíneas. Para produtividade, foi efetuada avaliação de massa seca. Os dados obtidos foram submetidos à análise de variância pelo teste $\mathrm{F}$ e comparação de média pelo teste de Tukey $(\mathrm{p} \leq 0,05)$. A sobrevivência de $D$. flavopicta foi maior em pastagem de $U$. decumbens do que em $U$. brizantha. O tratamento de sementes com tiametoxam reduziu a porcentagem de cigarrinhas sobreviventes em pastagens em formação, embora não tenha influenciado nas injúrias causadas pelo inseto-praga e na produtividade de massa seca das forrageiras.

PALAVRAS-CHAVE: cigarrinha-das-pastagens; Urochloa decumbens; Urochloa brizantha; manejo integrado de pragas. 


\section{INTRODUCTION}

Extensive culture of Urochloa (syn. Brachiaria) caused outbreaks of spittlebug populations (Hemiptera: Cercopidae), the main pests in the pastures of tropical America (COSENZA, 1981; VALÉRIO; NAKANO, 1988; SUJII et al., 2001). According to AUAD et al. (2009), signalgrass (U. decumbens) is more prone to attacks by the spittlebug when compared to other Brachiaria species. In addition to the genus Mahanarva, the species Deois flavopicta, Deois schach, Deois incompleta and Notozulia entreriana are extremely common in the South-Central region of Brazil among the spittlebugs that attack pastures (SILVEIRA NETO et al., 1992; RESENDE et al., 2013). Further, the species D. flavopicta was reported in signalgrass in the northwestern region of the state of São Paulo, Brazil (PEREIRA et al., 2011). Female spittlebugs usually lay their eggs on the ground or in vegetal remains. After eclosion, nymphs fix themselves at the base of the signalgrass and maintain themselves protected by characteristic foam (PEREIRA; PEREIRA, 1985; VALÉRIO, 2009).

Spittlebug nymphs suck the sap of the root and stalk on the soil's surface. Adults feed on the aerial section of the grass and inject it with toxins, giving it a yellowish color and causing it to wither. They also reduce crude protein, fat and essential minerals. Dry matter increases and the grass becomes less tasty. Consequently, the animal feed is reduced, decreasing the milk and beef production (HEWITT, 1988; VALÉRIO; NAKANO, 1988). In other words, decrease of pest population is a must. Liabilities are estimated in hundreds of millions of dollars a year. In the case of the Brazilian savannah, with an area planted with signalgrass reaching 15 million hectares, losses may range between 99 and 819 millions of dollars a year (MACEDO, 2005; HOLMANN; PECK, 2002; VALÉRIO, 2012).

Management and control methods for spittlebug in pastures include biological control by the fungus Metarbizium anisopliae, a substance with insecticides and resistant varieties (VALÉRIO; KOLLER, 1993; PEREIRA et al., 2008). However, high costs impair control measures, as well as lack of information and scarcity of specific insecticides against the spittlebug, scanty tolerant or resistant foragers, difficulties in acquisition and inconsistent results of biological control (TOWNSEND et al., 2001). Insecticides are frequently and mistakenly applied after the yellowing of pastures, as the symptom appears approximately three weeks after the spittlebug attack (SOUZA et al., 2008).

Seed treatment by insecticides, fungicides and nematicides for protection against pest-insects and phytopathogens is highly relevant for the development of robust and healthy plants (PARISI; MEDINA, 2014). One of the most important characteristics in the treatment of seeds by insecticides is the systemic effect on the plant, enhanced by low vapor pressure and solubility in water of the main active substances.
In fact, the ingredient releases itself slowly and is absorbed by the roots. The plant is thus protected against ground and aerial insects (SILVA, 1998).

Current analysis evaluates the dry mass yield and the survival and injuries caused by adult spittlebugs $D$. flavopicta in growing $U$. decumbens and $U$. brizantha pastures, submitted to seed treatments with insecticides fipronil $\left(\right.$ Amulet $\left.{ }^{\circledR}\right)$ and thiamethoxam (Cruiser 350 FS ${ }^{\circledR}$ ).

\section{MATERIALS AND METHODS}

\section{The experiment}

The assay was developed at the Research and Development Unit

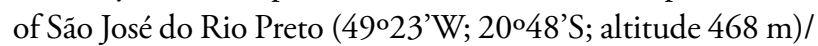
Agência Paulista de Tecnologia dos Agronegócios (APTA), between November, 2015 and January, 2016, within the context of the spittlebug $D$. flavopicta infesting pastures in the northwestern region of the state of Sáo Paulo, Brazil (PEREIRA et al., 2011). Experimental design comprised randomized blocks with six treatments $(2 \times 3)$ and four replications. Each parcel was made up of eight sowing rows, spaced $0.20 \mathrm{~m}$ and $4 \mathrm{~m}$ in length, totaling $6.40 \mathrm{~m}^{2}$. Treatments consisted of two species of signalgrass ( $U$. decumbens and $U$. brizantha), with seeds treated with insecticides fipronil $\left(\right.$ Amulet $\left.^{\oplus}\right)$, at $40 \mathrm{~mL}$ p.c. ha ${ }^{-1}$; thiamethoxam (Cruiser $350 \mathrm{FS}^{\circledast}$ ), at $300 \mathrm{~mL}$ p.c. $100 \mathrm{~kg}^{-1}$ seeds; control (without any treatment). Soil correction and preparation were undertaken in an area with remnant pasture for the establishment of the field assay.

\section{Application of the products}

Duly registered for signalgrass seed treatment, the products were applied to the seeds immediately before sowing, with broth volume proportional to $500 \mathrm{~mL} 100 \mathrm{~kg}^{-1}$ seeds, following technical recommendations (ANDREI, 2013). The seeds were placed in plastic bags, which were filled with air and sealed. These were the recipients in which pesticide and seeds were shaken and homogenized. After drying, seeds were sown manually with a distribution of $12.0 \mathrm{~kg} \mathrm{ha}^{-1}$ seeds (78\% of the crop value) of the two species of the Urochloa grass. Moreover, the establishment of the field assay was carried out taking into account favorable soil-climate conditions for the implantation of pastures.

\section{Infestation of adult $D$. flavopicta}

Spittlebug adults (D. flavopicta) were collected in remnant pastures for the standardization and uniformity of infestation in the experimental units. Insects were then selected in the laboratory and 20 specimens were inoculated per parcel (in a 
0.40x0.40x0.70 m cage), after 49 post-sowing days (Fig. 1). Population level and infestation period followed recommendations by VALÉRIO; NAKANO (1988) and RESENDE et al. (2013).

\section{Evaluation and data analysis}

The emergency of plants (stand) was evaluated at each parcel, recording the number of plants present in $0.5 \mathrm{~m}^{2}$, at 15 and 30 days after sowing (DAS).

Survival of D. flavopicta was calculated by counting the insects in the cages every two days after infestation, during 12 days, without replacing the dead ones. Rates were converted into percentages of surviving spittlebugs, at each evaluation, proportional to the initial population.

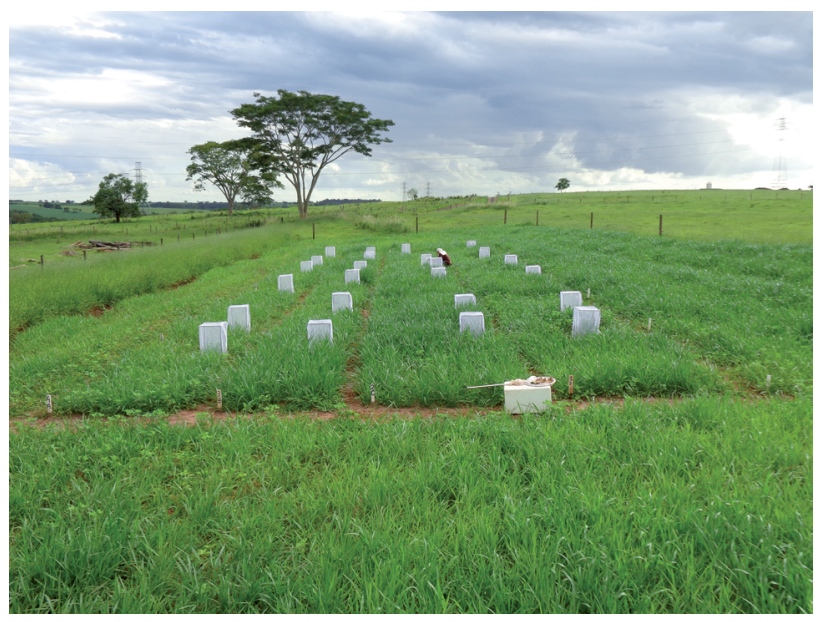

Figure 1. Infestation by $D$. flavopicta in the experimental units.
Injuries (yellowing) caused by spittlebug adults to signalgrass were assessed visually by four independent evaluators who gave marks (adapted by DAVIS; WILLIAMS, 1989) according to yellowing-withering percentages: $1-0$ at $20 \%$; $2-20 \%$ at $40 \% ; 3-40 \%$ at $60 \%$; $4-60 \%$ at $80 \%$ and $5-80 \%$ at $100 \%$, with $0=$ totally healthy plants; $100 \%=$ totally withered plants. Yield was calculated by signalgrass cutting and weighing of green mass. Later, vegetal biomass was conditioned in a forced-air buffer at $60^{\circ} \mathrm{C}$ to constant weight. Dry matter was then weighed. Evaluation occurred 70 days after sowing and data were converted into $\mathrm{kg} \mathrm{m}^{-2}$. Data underwent analysis of variance by F-test and means were compared by Tukey's test $(\mathrm{p} \leq 0.05)$.

\section{RESULTS AND DISCUSSION}

Analysis of variance showed that there was no significant interaction among the signalgrass species and insecticide-treated seeds on the survival of D. flavopicta in all evaluations (Table 1).

D. flavopicta population did not differentiate significantly the forage species at 2, 4, 6 and 8 days after infestation (DAI). However, overtime (on the $10^{\text {th }}$ and $12^{\text {th }} \mathrm{DAI}$ ) a greater percentage of spittlebugs survived in $U$. decumbens than in $U$. brizantha. The latter is resistant to spittlebugs, as reported by COSENZA (1981) and AUAD et al. (2009). The treatment of signalgrass seeds by insecticides fipronil and thiamethoxam failed to decrease $D$. flavopicta population at the $2^{\text {nd }}$ and $4^{\text {th }}$ DAI, when compared to grass without seed treatment (control). Therefore, on the $6^{\text {th }} \mathrm{DAI}$, the systemic

Table 1. Percentage of survivals of $D$. flavopicta in cages on $U$. decumbens and $U$. brizantha, submitted to seed treatment with insecticides. São José do Rio Preto SP Brazil, 2015/16.

\begin{tabular}{|c|c|c|c|c|c|c|}
\hline \multirow{2}{*}{ Treatment } & \multicolumn{6}{|c|}{ Days after infestation } \\
\hline & 2 & 4 & 6 & 8 & 10 & 12 \\
\hline U. decumbens & $58.33 a^{1 /}$ & $51.67 \mathrm{a}$ & $42.50 \mathrm{a}$ & $37.92 \mathrm{a}$ & $37.08 \mathrm{a}$ & $35.00 \mathrm{a}$ \\
\hline U. brizantha & $62.08 \mathrm{a}$ & $47.08 \mathrm{a}$ & $41.25 a$ & $36.25 \mathrm{a}$ & $28.75 b$ & $25.42 b$ \\
\hline$F(E)$ & 0.24 & 0.80 & 0.11 & 0.18 & 6.33 & 7.88 \\
\hline$P(E)$ & 0.6306 & 0.3859 & 0.7414 & 0.6749 & 0.0238 & 0.0133 \\
\hline control & $68.75 \mathrm{a}$ & $55.63 a$ & $49.38 \mathrm{a}$ & $40.63 \mathrm{a}$ & $36.88 \mathrm{a}$ & $34.38 a$ \\
\hline fipronil & $61.25 \mathrm{a}$ & $50.00 \mathrm{a}$ & $45.63 \mathrm{a}$ & $43.13 \mathrm{a}$ & $40.63 \mathrm{a}$ & $37.50 \mathrm{a}$ \\
\hline tiametoxam & $50.63 \mathrm{a}$ & $42.50 \mathrm{a}$ & $30.63 b$ & $27.50 b$ & $21.25 b$ & $18.75 b$ \\
\hline$F(T S)$ & 1.89 & 2.20 & 9.49 & 6.19 & 12.83 & 11.54 \\
\hline $\mathrm{P}(\mathrm{TS})$ & 0.1846 & 0.1458 & 0.0022 & 0.0110 & 0.0006 & 0.0009 \\
\hline$F(E \times T S)$ & 0.51 & 1.63 & 1.05 & 0.35 & 0.11 & 0.10 \\
\hline$P(E \times T S)$ & 0.6113 & 0.2291 & 0.3729 & 0.7073 & 0.8959 & 0.9016 \\
\hline CV (\%) & 31.08 & 25.46 & 21.75 & 25.74 & 24.65 & 27.68 \\
\hline
\end{tabular}

E: species of signalgrass. TS: treatment of seeds. ${ }^{1 /}$ Means followed by the same letter in the column do not differ by Tukey's test ( $p>0.05$ ). 
insecticide thiamethoxam significantly reduced the percentage of the surviving insects when compared to foragers without any chemical protection of the seeds. It also reduced those submitted to seed treatment with fipronil. Impact of thiamethoxam on cercopid adults remained during the other evaluations at $8^{\text {th }}, 10^{\text {th }}$ and $12^{\text {th }}$ DAI. The above may be related to the systemic activity of thiamethoxam with great efficaciousness in the control of sucker insects (GAZZONI, 2008). The study reveals that the treatment of signalgrass seeds with thiamethoxam (Cruiser $350 \mathrm{FS}^{\circledR}$ ), specifically employed for the control of termites in pastures (ANDREI, 2013), may be an asset in the population decrease of the spittlebug $D$. flavopicta in young pastures.

The number of $U$. decumbens and $U$. brizantha stands did not differ significantly among the different grass species and between the areas submitted or not to seed treatment with thiamethoxam and fipronil. In fact, the products (applied according to manufacturer's instructions) did not reveal any phytotoxicity to seeds and, consequently, to plant emergence (Table 2).

Injuries attributed to the forager attacked by spittlebug adults in the susceptible grass ( $U$. decumbens) were comparatively greater than those in the resistant one, regardless of the treatment of seeds by insecticides (Fig. 2). The above corroborates the resistance of $U$. brizantha to spittlebugs (VALÉRIO et al., 1997).

Fipronil and thiamethoxam, applied in the treatment of signalgrass seeds, failed to reduce significantly injuries by $D$. flavopicta, even though there was a higher yellowing rate in pasture without any chemical protection to seeds. Since there was a decrease in survival rates in grasses from seeds treated with thiamethoxam, it may be surmised that

Table 2. Number of plant stands; injuries caused by $D$. flavopicta adults; dry matter yield of $U$. decumbens and $U$. brizantha, submitted to seed treatments with insecticides. São José do Rio Preto SP Brazil, 2015/16.

\begin{tabular}{|c|c|c|c|c|}
\hline \multirow{2}{*}{ Treatment } & \multicolumn{2}{|c|}{ Stand - Plants. $\mathrm{m}^{-2}$} & \multirow{2}{*}{ Injuries $^{2 /}$} & \multirow{2}{*}{$\begin{array}{l}\text { Dry matter } \\
\text { kg. } \mathrm{m}^{-2}\end{array}$} \\
\hline & 12 DAS & 27 DAS & & \\
\hline U. decumbens & $147.67 a^{1 /}$ & $139.67 \mathrm{a}$ & $2.98 a$ & $0.533 \mathrm{a}$ \\
\hline U. brizantha & $128.00 \mathrm{a}$ & $117.17 \mathrm{a}$ & $1.50 b$ & $0.582 \mathrm{a}$ \\
\hline$F(E)$ & 4.22 & 2.92 & 20.78 & 0.60 \\
\hline$P(E)$ & 0.0577 & 0.1080 & 0.0004 & 0.4513 \\
\hline control & $140.00 \mathrm{a}$ & $140.00 \mathrm{a}$ & $2.56 \mathrm{a}$ & $0.509 a$ \\
\hline fipronil & $126.50 \mathrm{a}$ & $116.00 \mathrm{a}$ & 2.09 a & $0.616 a$ \\
\hline tiametoxam & $147.00 \mathrm{a}$ & $129.25 \mathrm{a}$ & $2.06 \mathrm{a}$ & $0.548 \mathrm{a}$ \\
\hline$F(T S)$ & 1.58 & 1.11 & 0.99 & 0.99 \\
\hline$P(T S)$ & 0.2382 & 0.3545 & 0.3934 & 0.3933 \\
\hline$F(E \times T S)$ & 1.17 & 1.05 & 1.49 & 0.15 \\
\hline$P(E \times T S)$ & 0.3372 & 0.3737 & 0.2573 & 0.8651 \\
\hline CV (\%) & 17.01 & 25.11 & 35.49 & 27.73 \\
\hline
\end{tabular}

E: species of signalgrass. TS: Treatment of seeds. DAS: Days after sowing. 1/Means followed by the same letter in the column do not differ by Tukey's test (p>0.05). ${ }^{2 / I}$ Injuries: $1: 0$ to $20 \%$; $2: 20$ to $40 \%$; $3: 40$ to $60 \% ; 4: 60$ to $80 \% ; 5: 80$ to $100 \% ; 0=$ healthy plants; $100 \%=$ withered plants.

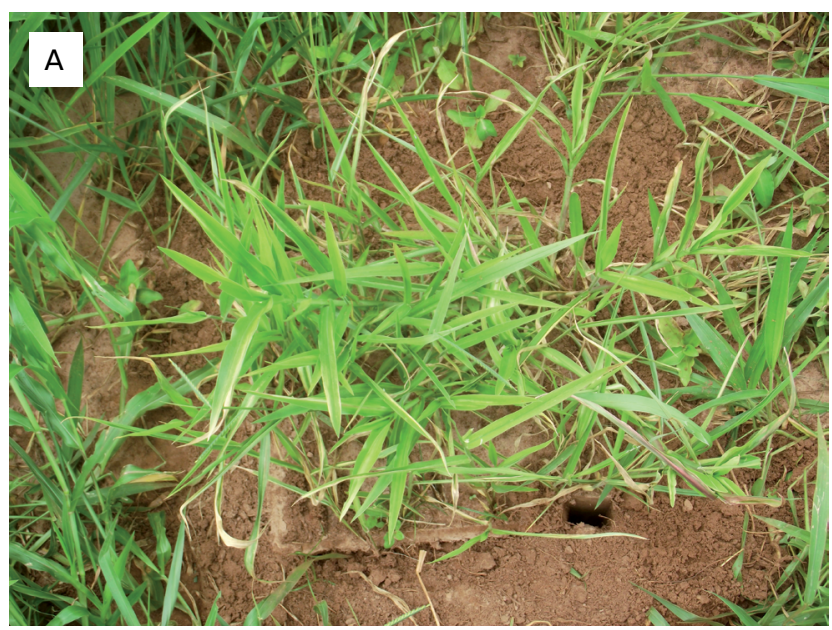

Figure 2. Injuries caused by $D$. flavopicta adults in U. decumbens (a) and U. brizantha (b). 
similarity in injuries perceived among the experimental units was probably due to high infestation rates (20 adults $\left.0.16 \mathrm{~m}^{-2}\right)$ of the spittlebugs in the cages and to the fact that defensive activities on the spittlebug occurred only after six days of infestation. During evaluation of the pest-insect, yellowing of the grass was perceived on the $2^{\text {nd }}$ and $4^{\text {th }}$ day after infestation. This fact differs from the report by SOUZA et al. (2008), who revealed that symptoms appeared about three weeks after the attack by the spittlebug.

Dry matter yield was significantly similar among species $U$. decumbens and $U$. brizantha, and between the areas submitted or not to seed treatment by insecticides. However, the yield of the resistant signalgrass was $9.15 \%$ times higher than that of the susceptible one. According to MARTUSCELLO et al. (2009), this fact may be related to the multi-stalk development of $U$. brizantha, which, aside from being a resistant variety to pest-insects, has high stalk production when compared to the growth of $U$. decumbens.

\section{CONCLUSION}

The treatment of signalgrass seeds with insecticide thiamethoxam may be an asset in decreasing the population of D. flavopicta in young pasture. However, it does not affect injuries caused by the pest insect and dry matter yield.

\section{ACKNOWLEDGEMENTS}

The authors would like to thank Fundação de Apoio à Pesquisa e Extensão de São José do Rio Preto (FAPERP) for funding the present research (Process 184/2015).

We thank the Conselho Nacional de Desenvolvimento Científico e Tecnológico (CNPq) and Fundação de Amparo à Pesquisa do Estado de Minas Gerais (FAPEMIG) for supporting our research.

| | | | | | | | | | | | | | | | | | | | | | | | | | | | | | | | | | | | | | | | | | | | | | | | | | | | | | | | | | | | | | | | | | | | | | | | | | | | | | | | | | | | | | | | | | | | | | | | | | | | | | | | | | | | | | | | | | | | | | | | | | | | | | | | | | | | | | | | | | | | | | | | | | | | | | | | | | | | | | | | | | | | | | | | | | | | | | | | | | | | | | | | | | | | | | | | | | | | | | | | | | | | | | | | | | | | | REFERENCES

ANDREI, E. Compêndio de Defensivos Agrícolas: Guia prático de produtos fitossanitários para uso agrícola. 9a ed, Organização Andrei Editora Ltda, 2013. $1618 \mathrm{p}$.

AUAD, A.M.; CARVALHO, C.A.; SILVA, D.M.; DERESZ, F. Flutuação populacional de cigarrinhas-das-pastagens em braquiária e capim-elefante. Pesquisa Agropecuária Brasileira, v.44, n.9, p.1205-1208, 2009. http://dx.doi.org/10.1590/ so $100-204 X 2009000900020$

COSENZA, G.W. Biologia e ecologia de pragas das pastagens. In: SIMPÓSIO SOBRE ECOSSITEMA DE PASTAGENS. Jaboticabal: FUNEP. 1989, p.87-96.

COSENZA G.W. 1981. Resistência de gramíneas forrageiras à cigarrinha-das-pastagens Deois flavopicta (Stal., 1854). Planaltina: EMBRAPA Cerrados. 1981. 16p. Boletim de Pesquisa, 7.

COSENZA, G.W., ANDRADE, R.P.; GOMES, D.T.; ROCHA, C.M.C. Resistência de gramíneas forrageiras à cigarrinha-das-pastagens. Pesquisa Agropecuária Brasileira, 24: p.961-968, 1989.

DAVIS, F.M.; WILLIAMS, W.P. Methods used to screen maize for resistance and to determine mechanisms of resistance to the Southwestern cornborer and fall armyworm. In: INTERNATIONAL SYMPOSIUM ON METHODOLOGIES FOR DEVELOPMENT HOST PLANT RESISTANCE TO MAIZE INSECTS. Toward insect resistance maize for the third world.CIMMYT, México, 1989, p.101-104.

FONTES, E.G.; PIRES, C.S.S.; SUJII, E.R. Mixed risk-spreading strategies and the population dynamics of a Brazilian pasture pest, Deois flavopicta (Homoptera: Cercopidae). Journal of Economic Entomology, v.88, n.5, p.1256-1262, 1995.
GAZZONI, D.L. Tiametoxam: Uma revolução na agricultura brasileira. GAZZONI, D.L. (coord.). Ed. Vozes - São Paulo, 2008.

HEWITT, G.B. Grazing management as a means of regulating spittlebug (Homoptera: Cercopidae) numbers in Central Brazil. Pesquisa Agropecuária Brasileira, v.23, n.7, p.697-707, 1988.

HOLMANN, F.; PECK, D.C. Economic damage causaed by spittlebugs (Homoptera: Cercopidae) in Colombia: A first approximation of impact on animal production in Brachiaria decumbens pastures. Neotropical Entomology, v.31, n.2, p.275-284, 2002. http://dx.doi.org/10.1590/ S1519-566X2002000200016

MACEDO, M.C.M. Pastagens no ecossistema Cerrado: evolução das pesquisas para desenvolvimento sustentável. In: SIMPÓSIO SOBRE PASTAGENS NOS ECOSSISTEMAS BRASILEIROS: alternativas viáveis visando a sustentabilidade dos ecossistemas de produção de ruminantes nos diferentes ecossistemas. Goiânia, Anais... Goiânia: SBZ. 2005. p.56-84.

MARTUSCELLO, J.A.; JANK, L.; GONTIJO NETO, M.M.; LAURA, V.A.; CUNHA, D.N.F.V. Produção de gramíneas do gênero Brachiaria sob níveis de sombreamento. Revista Brasileira de Zootecnia, v.38, n.7, p.1183-1190, 2009.

PARISI, J.J.D.; MEDINA, P.F. Tratamento de Sementes. Available from: http://pt.slideshare.net/ruralpecuariapecuaria/81-26834132. Access on: Jun 182014.

PEREIRA, M.F.A.; BORGES, R.S.; MENDES, E.E.B.; TOSCANO, L.C.; MORAES, R.F.O. Flutuação populacional de Deois flavopicta (Stal, 1854) em pastagem de Brachiaria decumbens. Boletín de Sanidad Vegetal: Plagas, v.37, n.2, p.173-179, 2011. 
PEREIRA, J.R.; PEREIRA, J.C.R. Cigarrinha das Pastagens: Importância e métodos de controle para a Zona da Mata de Minas Gerais. Coronel Pacheco: EMBRAPA Gado de Leite. 1985, 23p. Circular Técnica, 25.

PEREIRA, M.F.A.; BENEDETTI, R.A.L.; ALMEIDA, J.E.M. Eficiência de Metarhizium anisopliae (Metsch) Sorokin no controle de Deois flavopicta (Stal., 1854), em pastagem de capim-braquiária (Brachiaria decumbens). Arquivos do Instituto Biológico, v.75, n.4, p.465-469, 2008.

RESENDE, T.T.; AUAD, A.M.; FONSECA, M.G.; SOUZA SOBRINHO, F.; SANTOS, D.R.; SILVA, S.E.B. The damage capacity of Mahanarva spectabilis (Distant, 1909) (Hemiptera: Cercopidae) adult son Brachiaria ruziziensis pasture. Scientific World Journal, p. 1-6, 2013.

SILVA, M.T.B. Inseticidas na proteção de sementes e plantas. Seed News, Pelotas, n.5, p.26-27, 1998.

SILVEIRA NETO, S.; MARCHINI, L.C.; ALVES, S.B. Pragas das pastagens. In: Curso de entomologia aplicada à agricultura.

Piracicaba: FEALQ, 1992. p.335-353.

SOUZA, J.C.; SILVA, R.A.; REIS, P.R.; QUEIROZ, D.S.; SILVA, D.B Cigarrinhas-das-pastagens: histórico, bioecologia, prejuízos, monitoramento e medidas de controle. Belo Horizonte: Epamig, 2008. 8p. Circular Técnica, n.42.

SUJII, E.R.; PIRES, C.S.S.; FONTES, E.M.G.; GARCIA, M.A. Effect of host plant on the fecundity of spittlebug Deois flavopicta Stal (Homoptera: Cercopidae): implications on population dynamics. Neotropical Entomology, v.30, n.4, p.547-552, 2001.
TOWNSEND, C.R.; TEIXEIRA, C.A.D.; SILVA NETTO, F.G.; PEREIRA, R.G.A.; COSTA, N.L. Cigarrinhas-das-pastagens em Rondônia: diagnóstico e medidas de controle. Porto Velho: Embrapa-CPAF, 2001. 19p. Documentos, 53.

VALÉRIO, J.R. Cigarrinhas-das-pastagens. Artigo Técnico. 2012. Available from: http//pt.engormix.com/MA-pecuaria-corte/ administração/artigos/cigarrinhas-das-pastagens-t942/124-pO. htm. Access on: Apr 092014.

VALÉRIO, J.R.; NAKANO, O. Danos causados pelo adulto da cigarrinha Zulia entreriana na produção e qualidade de Brachiaria decumbens. Pesquisa Agropecuária Brasileira, v.23, n.5, p.447-453, 1988.

VALÉRIO, J.R.; KOLLER, W.W. Proposição para manejo integrado das cigarrinhas-das-pastagens. In: CURSO SOBRE PASTAGENS PARA SEMENTEIROS, CAMPO GRANDE. Campo Grande: Embrapa Gado de Corte. 1993, p.31-46.

VALÉRIO, J. R.; JELLER, H.; PEIXER, J. Seleção de introduções do gênero Brachiaria (Griseb) resistentes à cigarrinha Zulia entreriana (Berg) (Homoptera: Cercopidae). Anais da Sociedade Entomológica do Brasil, v.26, n.2, p.383-387, 1997.

VALÉRIO, J.R. Cigarrinhas-das-pastagens / José Raul Valério. Dados eletrônicos. - Campo Grande, MS : Embrapa Gado de Corte, 2009. 51 p.; $21 \mathrm{~cm}$. (Documentos / Embrapa Gado de Corte, ISSN 1983-974X, 179). Available from: < http://old. cnpgc.embrapa.br/publicacoes/doc/DOC 179.pdf > Access on: Ago 212016. 